\title{
Analisis implementasi manajemen strategi dalam meningkatkan mutu pendidikan pondok pesantren
}

\section{Imam Qori}

Magister Manajemen Universitas Trunojoyo Madura, Indonesia

e-mail: imam.qori@ymail.com

\begin{tabular}{|c|c|}
\hline \multicolumn{2}{|c|}{ Article Info: } \\
\hline Receive & Okt 2020 \\
\hline Revised & : Nop 2020 \\
\hline Accepted & : Des 2020 \\
\hline Published & : Des 2020 \\
\hline DOI & : 10.21067/mbr.v3i2.4605 \\
\hline Copyright & $\begin{array}{l}\text { : Management and } \\
\text { Business Review }\end{array}$ \\
\hline
\end{tabular}

Keywords: Strategy Management, Quality Of Education And Islamic Boarding School

\begin{abstract}
The purpose of this study was to analyze the implementation of management strategies in improving the quality of education at Al-Asror, using a qualitative descriptive approach. The primary data source for managing Al-Asror and secondary data is the Al-Asror handbook. The method of analysis used is the strategic management stage in the form of strategy formulation, strategy implementation and strategy evaluation. The results showed that in general AlAsror has implemented a management strategy in improving the quality of education. However, there are several strategic steps that have not been fulfilled properly, namely a lack of vision and mission, a lack of understanding of internal strengths and weaknesses, a lack of sense of belonging and a spirit of responsibility in developing the quality of education, so that strategy implementation cannot be carried out. done right. so is the lack of ability to make evaluative corrections.
\end{abstract}

\begin{abstract}
Abstrak: Tujuan penelitian ini adalah untuk menganalisis implementasi strategi manajemen dalam peningkatan mutu pendidikan Al-Asror, dengan pendekatan deskriptif kualitatif. Sumber data primer pengelola Al-Asror dan data sekunder berupa buku pegangan Al-Asror. Metode analisis yang digunakan dengan tahapan manajemen strategis berupa perumusan strategi, implementasi strategi dan evaluasi strategi. Hasil penelitian menunjukkan secara umum Al-Asror telah menerapkan strategi manajemen dalam meningkatkan mutu pendidikan. Namun terdapat beberapa langkah strategis yang belum terpenuhi dengan baik yaitu kurangnya visi dan misi, kurangnya pemahaman tentang kekuatan dan kelemahan internal, kurangnya rasa memiliki dan semangat tanggung jawab dalam mengembangkan kualitas pendidikan, sehingga implementasi strategi tidak dapat dilakukan. dilakukan dengan benar. begitu pula lemahnya kemampuan untuk melakukan koreksi evaluatif.
\end{abstract}




\section{Pendahuluan}

Hasil kajian terdahulu menyebutkan rendahnya mutu pendidikan dan daya saing pendidikan sekolah dan madrasah di Indonesia (Irani et al., 2014). Upaya peningkatan mutu terhadap pendidikan di pesantren yang sudah berjalan dengan baik (Purwanti et al., 2018). Sesuai amanat Undang-undang Republik Indonesia Nomor 20 tahun 2003 tentang Sistem Pendidikan Nasional menyebutkan bahwa pendidikan diperlukan oleh semua lapisan masyarakat dan seluruh bangsa indonesia. Bahkan karena begitu pentingnya pendidikan, pemerintah mewajibkan belajar 12 tahun (Undang-undang RI nomor 47 tahun 2008). Hal ini membuktikan bahwa pendidikan merupakan bagian dari penunjang kemajuan bangsa dan Negara.

Hasil kajian tersebut perlu menjadi perhatian banyak pihak, utamanya pemerhati pendidikan pesantren. Di sisi yang lain, pesantren mengalami perkembangan pendidikan yang signifikan. Di sisi yang lain pendidikan di Indonesia masih rendah.

Dinamika pendidikan selalu mengalami perubahan dan perkembangan sesuai keadaan zaman. Salah satunya terpotret dari lembaga pendidikan pesantren yang dulunya hanya terfokuskan dengan pendidikan keislaman, tapi saat ini pondok pesantren juga mengembangkan banyak bidang keilmuan; ekonomi, sosial kemasyarakatan, mulai tingkat dasar hingga tingkat perguruan tinggi. Pondok pesantren semakin menguat dan dipercaya sebagai lembaga pendidikan setelah diproklamirkan melalui sebuah undang-undang tentang pesantren, sesuai dengan UU nomor 18 tahun 2019.

Pondok pesantren sebagai lembaga pendidikan memiliki tanggung jawab untuk meningkatkan mutu pendidikan, baik pendidikan keagamaan atau pendidikan umum (Rahim, 2001). Itulah potret pendidikan pesantren saat ini, hal itu banyak dilakukan oleh banyak pesantren, begitu juga yang dilakukan pondok pesantren Al-Asror yang merupakan satu-satunya pondok Tahfizh AlQur'an yang menyelenggarakan pendidikan keislaman dan pendidikan umum yang ada di Bangkalan.

Pesantren yang didirikan 2007 ini menunjukkan perannya dalam bidang pendidikan. Pesantren yang secara khusus membidangi Al-Qur'an ini juga memiliki program-program unggulan, seperti adanya sekolah formal; Paket A, B dan C, SMPQ, diniah, kajian kitab kuning, Amtsilati, TPQ, Tahfizh Al-Qur'an, pengabdian dan beberapa Ekstra kurikuler, seperti Kursus Bahasa Arab dan Inggris, Tilawatil Qur'an, muhadloroh dan sebaginya, serta memberi kesempatan melanjutkan sekolah atau kuliah di luar pesantren.

Al-Asror banyak mencetak para Hafizh Al-Qur'an, dengan kemampuannya mereka bisa melanjutkan sekolah dan kuliah dengan jalur beasiswa, bahkan mereka diterima di berbagai perguruan tinggi terkenal di Indonesia, seperti UIN Malang, Universitas Brawijaya dan lainnya. Bahkan sebagian dari mereka ada yang diterima 
di Al-Azhar mesir. Mereka adalah orang-orang berprestasi di kampus masingmasing. Hingga saat ini, Al-Asror sudah memiliki alumni yang sarjana, Megister bahkan sudah ada yang melanjutkan jenjang Doktor. Sebagamana diungkap Imam, salah satu Alumni Al-Asror.

Hal ini adalah potret pesantren yang berwawasan global yang diharapkan saat ini, yakni pesantren yang selalu siap dan tanggap terhadap berbagai perubahan dan tuntutan perkembangan zaman, selalu mengutamakan dan mengupayakan prinsip efektivitas, efisiensi, kualitas dan lain sebagainya. Walaupun demikian, pesantren tidak harus mengubah dan mereduksi orientasi dan idealismenya sendiri. Nilai-nilai luhur pesantren tidak harus dikorbankan demi program-program penguatan eksistensi pesantren belaka. Kendati harus berubah dan menyesuaikan, atau bermetamorfosis dengan keadaan, dunia pesantren harus tetap hadir dengan jati dirinya yang memiliki kekhasan (Herman, 2018). Al-Asror tidak hanya fokus pada kajian keislaman, tapi juga kajian-kajian ekonomi dan sosial kemasyarakatan yang dibutuhkan sesuai tuntutan zaman.

Demikian itu tentu tidak lepas dari pengelolaan, manjemen dan strategi, sebagaimana dikemukakan oleh David \& David (2013) yang menyatakan bahwa manajemen strategi sebagai seni dan ilmu merumuskan, menerapkan, dan mengevaluasi keputusan lintas fungsional yang memungkinkan organisasi untuk mencapai tujuannya. Semua program yang dibuat oleh pesantren tentunya diterapkan setelah dirumuskan untuk mencapai tujuan lembaga yang memiliki wawasaan luas yang didasari oleh nilai-nilai kislaman.

Untuk memaksimalkan mutu pendidikan di Al-Asror, setidaknya mengimplementasikan tahap-tahap manajemen strategi yang dikemukakan oleh para pakar manajemen setrategi, mulai dari perumusan hingga evaluasi, yang memiliki manfaat, diantaranya adalah agar pondok pesantren menjadi dinamis, meningkatkan semangat pengurus ikut memiliki, berpartisipasi aktif dan bertanggung jawab (Sujadi, 2011). Oleh karena itu tujuan penelitian ini untuk menganalisis implementasi manajemen strategi dalam meningkatkan mutu pendidikan pondok pesantren Al-Asror Bangkalan.

\section{Manajemen Strategi}

Manajemen strategi berarti proses atau rangkaian-rangkaian kegiatan pengambilan sebuah keputusan yang sifatnya mendasar dan menyeluruh, disertai penetapan cara melaksanaannya, yang dibuat oleh manajemen puncak (manajer), kemudian diimplementasikan oleh semua jajaran di dalam suatu organisasi atau perusahaan untuk mencapainya (Nawawi, 2003). Manajemen strategi dapat diartikan sebagai sebuah seni dan ilmu untuk merumuskan, menerapkan dan mengevaluasi berbagai keputusan lintas fungsional yang memungkinkan organisasi untuk mencapai tujuannya (David \& David, 2013). 
Murniati (2008) menyebutkan bahwa manajemen strategi adalah kegiatan yang harus diselesaikan oleh manajemen puncak (manajer atau kepala) bersama tim secara terus-menerus, dan merupakan sebuah siklus yang mampu melahirkan keputusan untuk memenuhi relevansi dan hubungan kebutuhan sebuah organisasi dengan kebutuhan lingkungan. Deskripsi tersebut dapat dijelaskan bahwa manajemen strategi adalah sebuah upaya untuk memutuskan persoalan strategi, perencanaan strategi, dan bagaimana strategi tersebut mampu dilaksanakan serta dapat dievaluasi secara baik dan berkala.

\section{Tahapan Manajemen Strategi}

David \& David (2013) menjelaskan bahwa proses manajemen strategi terdiri dari 3 tahapan, yaitu: memformulasikan strategi, mengimplementasikan strategi dan mengevaluasi strategi.

a. Formulasi (Perumusan) Strategi

Perumusan strategi terdapat beberapa komponen, yaitu: mengembangkan visi dan misi, mengidentifikasi bebrbagai peluang dan ancaman eksternal sebuah organisasi, menentukan kekuatan dan kelemahan internal organisasi, menetapkan tujuan dalam jangka panjang, menghasilkan suatu alternatif strategi, dan memilih strategi tertentu yang sesuai dengan hasil analisis strategi di atas. Empat poin penting yang harus dilaksanakan dalam perumusan Strategi, yaitu: Perumusan Visi dan misi (mission determination), Asesmen lingkungan eksternal (environmental external assessment), asesmen organisasi (organization assessment), Penentuan strategi (strategi setting).

b. Implementasi Strategi

Implementasi strategi merupakan suatu langkah penerapan strategi yang telah melalui berbagai proses identifikasi berkenaan dengan faktor lingkungan eksternal dan faktor internal serta penyesuaian dengan tujuan perusahaan atau lembaga dalam berbagai kebijakan intensif, dimana setiap divisi dan fungsional perusahaan atau lembaga berkolaborasi dan bekerja sama sesuai dengan tugas dan fungsi masing-masing. Implementasi strategi merupakan proses dimana manajemen berusaha mewujudkan berbagai strategi dan kebijakannya dalam tindakan melalui pengembangan program-program, rancangan anggaran, dan prosedur (Dewi \& Sandora, 2019).

c. Evaluasi Strategi

Evaluasi dalam manajemen strategi meliputi kegiatan mengamati apakah strategi yang direncanakn berjalan sesuai harapan atau tidak. Evaluasi Strategi mencakup beberapa poin penting (Taufiqurokhman, 2016):

1) Mereview dan menelaah faktor-faktor ekternal dan internal yang merupakan basis bagi setiap strategi yang sedang berlangsung.

2) Mengukur jalannya kinerja. 
3) Mengambil tindakan perbaikan dan perubahan jika terjadi ketidak sesuaian dengan formulasi strategi.

\section{Keuntungan dan Manfaat Manajemen Strategi}

Manajemen strategi menjadikan sebuah organisasi lebih proaktif dari pada reaktif dalam membentuk masa depan organisasi itu sendiri, manajemen strategi menjadikan organisasi mampu dalam memulai dan mempengaruhi aktivitasaktivitasnya dan pada puncaknya diharapkan dapat menggunakannya untuk mengontrol jalan hidupnya (Sujadi, 2011).

Berdasarkan kajian sejarah, manfaat yang paling utama dari manajemen strategi adalah membantu organisasi dalam merumuskan berbagai strategi yang lebih baik dan bijak melalui penggunaan pendekatan yang lebih sistematis, logis, dan rasional pada alternatif strategi.

Semakin banyak perusahaan, organisasi dan lembaga yang mengaplikasikan manajemen strategi untuk membuat keputusan yang lebih efektif dan terarah. Tetapi, manajemen strategi tidak menjamin sebuah keberhasilan dan dapat menggangu jika dilakukan secara serampangan dan tidak beraturan.

a. Keuntungan Finansial

Perusahaan dan organisasi yang menggunakan konsep manajemen strategi menunjukkan peningkatan yang sangat signifikan dalam promusi, penjualan, keuntungan, dan lebih banyak produktivitas dibandingkan dengan perusahaan yang tidak menggunakan aktivitas perencanaan yang sistematik.

b. Keuntungan Non-Finansial

Selain membantu perusahaan untuk menghindari tersendatnya finansial, manajemen strategi menawarkan pula keuntungan-keuntungan lainnya, seperti penguatan kesadaran terhadap ancaman eksternal, pemahaman yang lebih meningkat terhadap strategi-strategi pesaingan, peningkatan produktivitas pekerja dan pegawai,minimnya perlawanan untuk banyak berubah, dan pemahaman yang lebih jelas terhadap hubungan performa dengan upah (David \& David, 2013).

\section{Pondok Pesantren}

Lembaga Research atau penelitian tentang Islam mengartikan pesantren sebagai suatu tempat atau lembaga pendidikan dan pengajaran yang menekankan pada pelajaran tentang pengethauan agama islam yang didukung dengan asrama atau pemondokan sebagai temapat tinggal santri yang bersifat tetap (Qomar, 2005).

Model pendidikan di pondok pesantren merupakan salah satu bentuk pendidikan yang berbasis pada masyarakat, karena kemajuan, berkembang atau mundurnya, bahkan kepemilikannya diserahkan semuanya terhadap masyarakat. Namun, seiring dengan perkembangan zaman, pesantren telah melakukan banyak perubahan dan pembaharuan secara signifikan. Selain psantren mengajarkan 
pendidikan tentang materi keislaman, beberapa pesantren saat ini juga telah banyak mengembangkan materi-materi pendidikan lainnya, baik dalam pendidikan formal atau non formal, seperti keterampilan, ektrakurikuler, kesenian, pengembangan bahasa asing, pendidikan jasmani dan lain sebagainya.

Manajemen pendidikan islam merupakan suatu proses penataan atau pengelolaan lembaga-lembaga pendidikan Islam yang melibatkan SDM muslim (kiyai dan ustadz) dan menggerakkannya untuk mencapai tujuan-tujuan pendidikan Islam secara efektif dan efisien yang tidak boleh dilakukan tanpa manajemen yang baik. Adapun manajemen pendidikan pondok pesantren adalah suatu proses pengelolaan lembaga pendidikan yg melibatkan sumber daya manusia (SDM) dan non manusia untuk mencapai tujuan pendidikan pesantren dengan efektif dan efisien." Jadi, manajemen pesantren merupakan bagian penting dari pendidikan itu sendiri (Sulistyorini, 2009).

\section{Metode}

Jenis penelitian ini menggunakan pendekatan deskriptif kualitatif, dimana peneliti sebagai instrumen utama, pengambilan sampel dilakukan secara pusrposive dan snowbaal, teknik pengumpulan data menggunakan triangulasi, analisis data bersifat induksi dan hasil penelitiannya lebih mengutamakan adanya makna.s

Penelitian ini dilakukan pada tahun 2020 bertempat di Pondok Pesantren Tahfizh Al-Qur'an Al-Asror Jalan Soekarno Hatta No 32c Mlajah Bangkalan. Data primer diperoleh dari pengurus pondok pesantren, sedangkan data sekunder berupa publikasi, brosur, struktur organisasi dan buku pedoman dan panduan pondok pesantren. Teknik pengumpulan data menggunakan wawancara, dokumentasi dan observasi. Teknik analisis data dengan tahapan Manajemen strategi yang terdiri dari 3 tahap, yaitu: formulasi strategi, implementasi strategi dan evaluasi strategi. Analisis data terdiri dari (a) reduksi data yang berarti merangkum data yang dihasilkan selama proses penelitian dengan cara memilah dan memilih hal-hal pokok sesuai kebutuhan penelitian. (b) Penyajian data yang dimaksudkan untuk mendeskripsikan hasil wawancara sesuai jawaban narasumber. Dengan ini peneliti dapat memahami apa yang sedang terjadi pada lembaga. (c) Verifikasi data yang dilakukan untuk mencari relevansi data yang sudah dihasilkan dengan teori-teori yang sudah ada (Sugiyono, 2011).

\section{Pembahasan}

Hasil analisis manajemen strategi dalam meningkatkan mutu pendidikan di pondok pesantren bisa dideskripsikan melalui tahapan-tahapan berikut:

\section{Formulasi Strategi}

Dalam formulasi strategi, setidaknya terdiri dari beberapa kegiatan, yaitu: 
1. Mengembangkan visi misi dan tujuan

Dalam memformulasikan strategi, pengurus pondok pesantren melakukan koordinasi antar pengurus dan pengasuh untuk merumuskan dan merencanakan kegiatan-kegiatan atau program-program yang akan dilaksanakan. Kegiatan ini diawali dengan menetapkan tujuan-tujuan program setelah menganalisis adanya kebutuhan. Walaupun visi dan misi tidak tertulis secara nyata, akan tetapi rumusan kegiatan selalu dilaksanakan berjangka minimal setiap awal semester atau awal tahun dan pada saat akan diadakan kegiatan yang bersekala besar. Sebagaimana diungkapkan Responden 1 (R1). Dan menetapkan tujuan-tujuan jangka pendek, menengah, dan jangka panjang. Dan (R6) menyatakan setidaknya 6 kali dalam setahun mengadakan rapat kordinasi.

Semua tujuan itu dalam rangka mengembangkan mutu pendidikan di pondok pesantren yang secara khusus mengembangkan Tahfizd Al-Qur'an. Rumusan tujuan inti pondok pesantren adalah "Membentuk pribadi muslim yg bermental Qur'ani" dan "Meng-Al-Qur'ankan masyarakat dan memasyarakatkan AlQur'an". Tujuan ini oleh R5 disebut sebagai Visi, akan tetapi tidak ada misi yang secara jelas dan tertulis.

Visi misi itu sangat diperlukan dalam organisasi, karena dengan adanya visi misi yang jelas, menjadikan pelaku organisasi (pengurus pondok) menjadi fokus dan jelas arah kerjanya. Oleh karena itu, para pengurus Al-Asror harus membuat visi misi ini sebagai acuan kerja yang terarah.

2. Mengidentifikasi kesempatan dan hambatan eksternal

Pengurus pesantren bersama pengasuh menganalisa kesempatan dan hambatan yang kemungkinan datang dari luar pesantren (ekstrnal), hal itu dimaksudkan agar program yang sedang direncanakan dapat memberikan manfaat lebih banyak dan memberikan kontribusi pada kemajuan pendidikan di pesantren. Terlebih khusus bisa memberikan manfaat bagi masyarakat luas. Akan tetapi usaha dalam mengidentifikasi ini belum maksimal.

3. Menentukan kekuatan dan kelemahan internal

Pengasuh sebagai manajer lembaga selalu memberikan pembinaan dan arahan serta intruksi terhadap para pengurus yang ada di pondok pesantren, akan tetapi mereka lemah dan terlambat dalam memahami kekuatan dan kelemahan internal mereka sendiri. Hal itu disebabkan karena kurangnya rasa memiliki terhadap lembaga, kurangnya koordinasi antar pengurus dan lemahnya rasa ingin mengembangkan lembaga (R2). Yang demikian itu terlihat dari beberapa hal berikut:

a) Kurangnya kontribusi saat mengadakan koordinasi, hanya beberapa pengurus yang mengajukan pendapat. Walaupun kadang memiliki keinginan yang diutarakan, akan tetapi mereka memilih diam.

b) Saat melaksanakn program-program hanya dikomandoi segelintir orang saja. 
c) Kurangnya kesadaran rasa bertanggung jawab dan rasa memiliki terhadap organisasi. Sebagaimana diungkap oleh Sujadi (2011), bahwa merasa memiliki itu bagian dari manfaat dari implementasi manajemen strategi.

\section{Menentukan strategi}

Setelah tujuan program ditentukan, pengurus bersama pengasuh membuat strategi untuk mencapai tujuan tersebut. Strategi dibuat untuk mengembangkan mutu pendidikan di pesantren, baik pendidikan keagamaan atau keislaman, ataupun pendidikan umum. Untuk mengetahui strategi tersebut bisa dilihat dari beberapa program-program berikut:

a) Program ke-Al-Qur'anan, yang berupa Tahfidz Al-Qur'an khusus bagi yang ingin menghafal, membacanya bin-Nadzar (program khatam 30 juz dan tahsin Al-Qur'an) yang harus diikuti oleh semua santri dan TPA khusus bagi pemula.

b) Program baca kitab kuning; berupa program khusus Amtsilati (metode cepat baca kitab), program diniyah dan kajian-kajian kitab kuning yang harus dikiti seluruh santri.

c) Sekolah formal; yaitu SMPQ untuk menfasilitasi santri yang belum bisa melanjutkan sekolah formal di luar pesantren dan Program paket A, B dan C bagi santri yang tidak berkesempatan mengikuti sekolah dan madrasah formal dan ingin melanjutkan pendidikannya.

d) Kegiatan ekstra kurikuler untuk menunjang kompetensi atau minat santri, seperti pengembangan bahasa arab dan inggris, Tialawatil Qur'an dan tim sholawat.

e) Serta pengembangan majalah untuk mengasah kemampuan menulis dan berfikir santri.

Namun demikian, "Strategi yang dibuat untuk melaksanakan program ini belum maksimal, karena kurangnya rasa tanggung jawab pengurus dan santri, kuranganya semangat memiliki, kurang kompak dan rasa ingin maju". Sebagaimana diungkap oleh R2. Tidak adanya visi-misi yang jelas, sehingga rencana dan keinginan tidak memiliki acuan yang jelas pula, gagal dalam memahami kekuatan dan kelemahan internal serta hambatan eksternal. Sehingga tidak maksimal dalam menentukan dan memformulasikan strategi.

\section{Implementasi Strategi}

Implementasi ini merupakan perwujudan dari tujuan dan rumusan-rumusan yang sudah ditentukan sebelumnya (David \& David, 2013), dalam implementasi ini terdiri dari beberapa kegiatan, yaitu:

a) Mengembangkan budaya yang mendukung strategi

Budaya yang dikembangkan di Al-Asror adalah melaksanakan semua program sesuai jadwal yang sudah ditentukan sebelumnya. Jadwal terdiri dari: (1) jadwal harian, seperti tahfidz Al-Qur'an, tahsinul Qur'an, TPQ, diniyah dan solat brjema'ah. (2) jadwal mingguan, seperti ekstra kurikuler. (3) jawal bulanan, yaitu: 
pelaksanaan muhadloroh dalam rangka mengembangkan inovasi santri. (4) Jadwal Tahunan, terdiri ajang kreatifitas santri, seminar dan pelatihan untuk menambah wawasan keilmuan santri.

b) Membuat struktur organisasi

Struktur organisasi sudah dibuat, yang terdiri dari pembina, pengasuh, para ketua pondok, penanggung jawab bidang tertentu hingga pada pelaksana program dan kegiatan. (Dokumentasi Al-Asror). Struktur ini biasanya diperbaharui setiap tahuan, atau pada setiap ada perubahan mendesak, seperti adanya salah satu bagian dari struktur yang berhenti atau keluar dari struktural kepengurusan pondok.

c) Menyiapkan anggaran

Anggaran di pondok pesantren Al-Asror berasal dari iuran bulanan dan tahunan santri serta donatur pondok. Walaupun anggaran dana terkadang tidak maksimal dan harus ada iuran tambahan, tapi kegiatan bisa dilaksanakan sesuai dana seadanya.

d) Mengembangkan dan memanfaatkan sistem informasi

Sistem informasi di pesantren sangat sulit dikembangkan, karena adanya aturan yang tidak membolehkan santri untuk membawa HP atau laptop dan keterbatasan kemampuan pengurus untuk mengembangkan sistem informasi, sehingga semua program dilaksanakan dengan cara manual. Hanya ada beberapa inovasi-inovasi pada program-program tertentu, kegiatan tahunan dan bulanan. Sebagaimana diungkapkan (R3).

Dari beberapa pemaparan di atas, bisa disimpulkan bahwa implementasi strategi di Al-Asror dalam mengembangkan mutu pendidikan, kurang maksimal. Hal itu disebabkan karena formulasi strategi yang juga tidak maksimal, serta kurangnya motivasi dan semangat para pengurus dalam mengemban amanah dan lemahnya rasa memiliki, sehingga anggapan mereka yang penting kegiatan atau program bisa dilaksanakan.

\section{Evaluasi Strategi}

Fungsi pokok evaluasi agar manajer atau pemimpin puncak dapat mengetahui informasi tentang keberhasilan strategi yang telah dilaksanakan (David \& David, 2013). Di pondok Al-Asror yang bertindak sebagai manajer adalah pengasuh pondok.

Faktor eksternal pesantren menjadi salah satu bahan review pengurus dalam mengembangkan inovasi pendidikan atau bahkan memperbaiki program yang sudah dijalankan, jika memang kurang efektif. Hal itu tergambar dari respon pengurus saat ada situasi eksternal yang mengganggu mutu pendidikan pesantren atau adanya program yang harus dikembangkan, yaitu dengan melakukan rapat kordinasi atau instruksi langsung dari pengasuh (sebagai manajer) secara langsung. Dengan keterbatasan SDM pengurus pesantren, mereka masih melakukan review 
terhadap situasi yang terjadi di sekitarnya. Walaupun hal itu belum bisa dilaksanakan dengan baik dan maksimal.

Namun, para pengurus pesantren lemah dalam meng-evaluasi atau mereview faktor internal yang dapat mengganggu atau menurunkan mutu pendidikan di pesantren yang datang dari internal pesantren. Hal itu terlihat dari minimnya evaluasi diri pengurus dalam menjalankan atau mengimplementasikan strategi yang sudah disepakati, minimnya kesadaran untuk memperbaiki internal mereka dan kurangnya motivasi untuk mengembangkan strategi dan program yang sudah dibuat bersama. Hanya beberapa orang yang memiliki kesadaran itu, sehingga mengganggu jalannya program yang sudah dibuat (R4).

Visi dan misi harusnya menjadi acuan dalam mengevaluasi ketercapaian strategi. Namun, karena visi dan misi tidak tertulis, maka evaluasi hanya terbatas pada berjalan dan tidaknya strategi, bukan pada ketercapaian dan pengembangan mutu pendidikan. Evaluasi juga dilakukan saat akan memasuki tahuan ajaran baru, sebagai sebuah persiapan dan memperbaiki hal-hal yang kurang maksimal pada tahun sebelumnya.

Program-program pesantren yang utama, seperti tahfidz Al-Qur'an menjadi icon program pesantren yang bisa dibanggakan dan diunggulkan, karena setiap tahuan mengalami peningkatan. Hal ini karena adanya evaluasi dan perbaikan yang intensif, wlaupun masih banyak yang perlu diperbaiki, seperti motivasi santri, sebagai orang yang langsung melaksanakan strategi atau program. Di sisi yang lain, pendidikan kaislaman yang masih stagnan, mutu pendidikan formal dan umum banyak di dapat oleh santri dari luar pesantren.

Pada intinya, pengasuh terlambat mendapatkan laporan dari para pengurus, sedangkan pengurus juga terlambat dalam memahami dinamika internal pesantren, sehingga mutu pendidikan pesantren secara eksternal mengalami peningkatan, kerena semua program bisa dilaksanakan. Tetapi secara internal ada banyak hal yang perlu diperbaiki. Oleh karena itu, dalam tahap evaluasi ini, pesantren sudah melaksanakan evaluasi terhadap ketercapaian strategi. Namun belum maksimal dalam melakukan perbaikan. Hal itu disebabkan karena keterbatasan SDM pengurus pesantren, sebagai pengelola.

Secara umum, mutu pendidikan di pondok pesantren Tahfidz Al-Qur'an AlAsror mengalami perkembangan, selalu ada inovasi dan semua rencan kegiatan bisa dilakukan. Dalam analisis strategi manajemen, banyak hal yang harus dilakukan dan diperbaiki oleh pengelola pesantren, diantaranya; mempertegas visi-misi, memahami dan memperbaiki kekuatan dan kelemahan internal, meningkatkan motivasi, kesadaran akan memiliki dan tanggung jawab atas amanah sehingga strategi yang dibuat bisa diimplementasikan sesuai kebutuhan dan tujuan, serta evalusi berkala untuk memperbaiki kekurangan dan kelemahan. 


\section{Simpulan}

Mutu pendidikan di Pondok Pesantren Tahfidz Al-Qur'an "Al-Asror" secara umum mengalami peningkatan. Namun, dilihat dari implementasi manajemen strategi, ada banyak tahapan yang perlu diperbaiki. Dalam memformulasikan strategi, pesantren tidak memiliki visi dan misi yang bisa menjadi acuan dan lemah dalam memahami kekuatan dan kelemahan internal. Sehingga tidak maksimal dalam mengimplementasikan strategi, karena pengelola tidak memiliki acuan yang bisa dijadikan pegangan dalam melaksanakan strategi. Evaluasi sudah dilakukan dengan berbagai upaya, akan tetapi karena keterbatasan kemampuan SDM yang ada, semangat, rasa memiliki dan tanggung jawab yang lemah dan minimnya sistem yang memadai, sehingga lambat dalam memberikan perbaikan-perbaikan. Secara umum, Implemtasi manajemen di pondok pesantren Tahfidz Al-Qur'an Al-Asror sudah dilaksanakan, namun belum berjalan secara baik.

Oleh karena itu, pengelola pesantren perlu melakukan pembinaan intensif, mengadakan training dalam rangka memahami pengelolaan pesantren yang baik dan berusaha memahami kekuatan dan kelemahan internal secara baik dengan melakukan evaluative korektif. Perlu meningkatkan semangat, rasa memiliki terhadap organisasi dan rasa tanggung jawab yang kuat, sehingga mutu pendidikan di pondok psantren tahfidz Al-Al-Qur'an Al-Asror semakin berkembang.

\section{Daftar Pustaka}

David, F. R., \& David, F. R. (2013). Strategic management: Concepts and cases: A competitive advantage approach. Pearson.

Dewi, R., \& Sandora, M. (2019). Analisis Manajemen Strategi UIN Suska Riau dalam Mempersiapkan Sarjana yang Siap Bersaing Menghadapi Mea. Jurnal ELRIYASAH, 10(1), 74-91.

Herman, I. (2018). Revitalisasi Peran Pesantren dalam Pengembangan Sumber Daya Umat di Era Globalisasi dan Modernisasi. CENDEKIA: Jurnal Studi Keislaman, 2(2).

Irani, U., Murniati, \& Khairuddin. (2014). Implementasi Manajemen Strategik dalam Upaya Peningkatan Mutu Pendidikan pada SMAN 10 Fajar Harapan. Jurnal Administrasi Pendidikan Pascasarjana Universitas Syiah Kuala, 4(2), 58-70.

Murniati, A. R. (2008). Manajemen Stratejik: Peran kepala sekolah dalam pemberdayaan. Perdana Publishing.

Nawawi, H. (2003). Manajemen Strategik: Organisasi Non Profit Bidang Pemerintahan dengan Ilustrasi Di Bidang Pendidikan: Yogyakarta. Gadjah Mada University Press. 
Purwanti, E., Kusuma, N., \& Sari, R. N. (2018). Implementasi Manajemen Strategis dalam Upaya Peningkatan Mutu Pendidikan di Pondok Pesantren: Indonesia. Jurnal Manajemen Pendidikan Islam Al-Idarah, 3(2), 85-92.

Qomar, M. (2005). Pesantren: dari transformasi metodologi menuju demokratisasi institusi. Erlangga.

Rahim, H. (2001). Pembaharuan Sistem Pendidikan Nasional: Mempertimbangkan Kultur Pondok Pesantren. Jakarta: Logos Wacana Ilmu.

Sugiyono. (2011). Metodologi penelitian kuantitatif kualitatif dan R\&D. In Alpabeta, Bandung. Alfabeta.

Sujadi, S. (2011). Konsep Manajemen Strategik Sebagai Paradigma Baru Di Lingkungan Organisasi Pendidikan. Jurnal STIE Semarang, 3(3), 18-30.

Sulistyorini, S. (2009). Manajemen Pendidikan Islam. Yogyakarta: Teras.

Taufiqurokhman, T. (2016). Manajemen Strategik. Fakultas Ilmu Sosial dan Ilmu Politik. 